\title{
Observations of Foothill Yellow-legged Frog predation by a native frog, snake, and giant water bug in a central California intermittent stream
}

\author{
Robert A. Leidy ${ }^{1}{ }^{*}$, Rachael Ryan ${ }^{2}$, Hana Moidu $^{2}$, Pablo Rodríguez-Lozano ${ }^{2}$, \\ Michael T. Bogan ${ }^{3}$, and Stephanie M. Carlson ${ }^{2}$ \\ ${ }^{1}$ U.S. Environmental Protection Agency, San Francisco, CA 94105 \\ ${ }^{2}$ Department of Environmental Science, Policy, and Management, University of California, Berkeley, CA 94720 \\ ${ }^{3}$ School of Natural Resources and the Environment, University of Arizona, Tucson, AZ 85721
}

\begin{abstract}
During the summers of 2015 and 2018, we observed predation on Foothill Yellow-legged Frogs (Rana boylii) by a giant water bug (Abedus indentatus), a California Red-legged Frog (Rana draytonii), and a Diablo Range Gartersnake (Thamnophis atratus zaxanthus) adjacent to 3 separate isolated pools along intermittent reaches of Coyote Creek, Santa Clara County, California, USA. To the best of our knowledge, our observations provide the first published record of California Red-legged Frog and giant water bug preying upon Foothill Yellow-legged Frogs. As pool habitat contracts over the course of the dry season, locally abundant Yellow-legged Frogs may be increasingly vulnerable to predation from a suite of aquatic and terrestrial predators.
\end{abstract}

RESUMEN.-Durante los veranos de 2015 y 2018, observamos tres eventos de depredación sobre individuos de rana patiamarilla (Rana boylii) por parte de una chinche acuática (Abedus indentatus), una rana de patas rojas californiana (Rana draytonii) y una culebra acuática (Thamnophis atratus zaxanthus) en 3 pozas aisladas a lo largo de un río intermitente (Coyote Creek, Santa Clara County, California, USA). Hasta donde sabemos, estas son las primeras observaciones publicadas sobre Rana draytonii y Abedus indentatus depredando individuos de Rana boylii. Nuestras observaciones sugieren que Rana boylii podría ser más vulnerable a depredadores tanto acuáticos como terrestres conforme la estación seca avanza y el hábitat acuático disponible disminuye.

The Foothill Yellow-legged Frog (Rana boylii) occurs on the Pacific Slope of North America, from west central Oregon and California to northwestern Baja California, where its populations have experienced widespread declines (Thomson et al. 2016). Within the Diablo Range of central California, Foothill Yellow-legged Frogs remain locally common along the shallow riffles and permanent pools of intermittent streams, which are characterized by sand-cobble substrates interspersed with large boulders and bedrock outcrops. As the dry season advances, intermittent streams contract to a series of isolated pools, some of which persist until the first rains reconnect these habitats. These same pools also serve as dry-season refuges for California Red-legged Frog (Rana draytonii), Diablo Range Gartersnake (Thamnophis atratus zaxanthus), and a flightless giant water bug (Abedus indentatus), among other native aquatic invertebrates and vertebrates (Bogan et al. 2019). On warm summer and fall days, congregations of Foothill Yellow-legged Frogs may be observed basking on the sun-exposed edges of isolated pools.

During a stream survey on 21 September 2015 of aquatic invertebrates and vertebrates along intermittent reaches of Coyote Creek, Santa Clara County, California, USA, we observed predation on a young adult Foothill Yellow-legged Frog (approximately $45 \mathrm{~mm}$ snout-vent length) by an adult giant water bug (A. indentatus) (approximately $35 \mathrm{~mm}$ total length) in an isolated pool $\left(37^{\circ} 8^{\prime} 33.99^{\prime \prime} \mathrm{N}\right.$, $\left.121^{\circ} 29^{\prime} 12.87^{\prime \prime} \mathrm{W}\right)$ (Fig. 1). The giant water bug was perched at the shallow edge of the pool, with its breathing straps at the surface of the water, injecting digestive enzymes into its prey

*Corresponding author: leidy.robert@epa.gov 


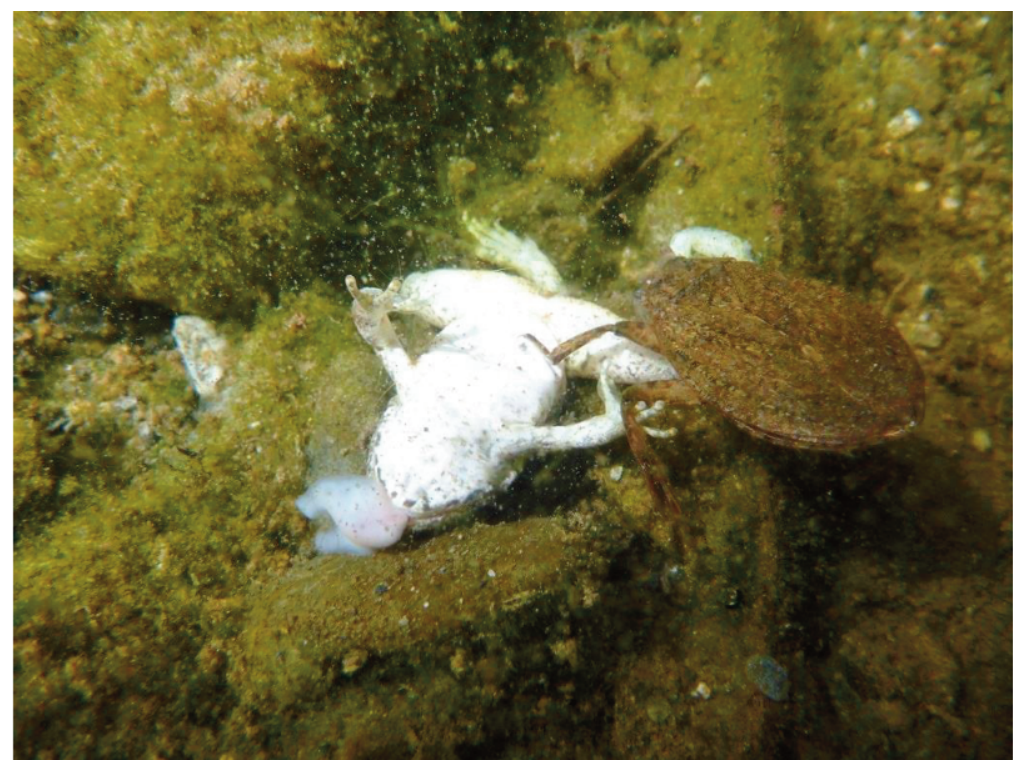

Fig. 1. Giant water bug (Abedus indentatus) with captured Foothill Yellow-legged Frog (Rana boylii) within an isolated pool, along Coyote Creek, Diablo Range of central California, USA. Photo by M.T. Bogan.

via its beak-like mouthparts. Occasional movements of the frog's legs confirmed that it was preyed upon while still living, rather than being scavenged after death.

During subsequent stream surveys of aquatic vertebrates in Coyote Creek on 8 September 2018, we observed predation on Foothill Yellow-legged Frogs by California Red-legged Frog and Diablo Range Gartersnake adjacent to 2 isolated pools separated by $1.92 \mathrm{~km}$. At the first pool $\left(37^{\circ} 8^{\prime} 6.80^{\prime \prime} \mathrm{N}, 121^{\circ} 29^{\prime} 2.57^{\prime \prime} \mathrm{W}\right.$; 319 m elevation; time 10:25), we observed a large-sized female Red-legged Frog (125 mm snout-vent length) perched on a narrow, sunexposed bedrock ledge approximately $15 \mathrm{~cm}$ above the pool's water surface. The Redlegged Frog had partially swallowed headfirst a Foothill Yellow-legged Frog (approximately 50-60 mm snout-vent length), with the prey's hind limbs below the knees protruding from its mouth. Startled by our presence, the Redlegged Frog jumped into the pool and immediately regurgitated the Foothill Yellow-legged Frog, which then escaped.

The second Foothill Yellow-legged Frog predation event in 2018 occurred adjacent to another isolated pool $\left(37^{\circ} 7^{\prime} 11.50^{\prime \prime} \mathrm{N}, 121^{\circ}\right.$ $28^{\prime} 51.12^{\prime \prime} \mathrm{W} ; 304 \mathrm{~m}$ elevation; time 15:00). At this pool, we hand-caught a neonate Diablo Range Gartersnake (total length ca. $25 \mathrm{~cm}$ ) on the downstream water's edge. Following capture, the gartersnake immediately regurgitated headfirst a dead Foothill Yellow-legged Frog (ca. 35 mm snout-vent length) (Fig. 2).

We believe our observations are the first published record of adult California Redlegged Frog and giant water bug preying upon adult Foothill Yellow-legged Frogs. Giant water bugs (Hemiptera: Heteroptera: Belostomatidae) have been observed preying on a diversity of aquatic and semiaquatic animals, including insects, crustaceans (amphipods and cladocerans), frogs, fish, turtles, and birds (citations in Ohba 2018). However, predation on vertebrates by giant water bugs is most commonly carried out by the genus Lethocerus (55-90 mm total length), rather than by the smaller genera Abedus and Belostoma (20-40 $\mathrm{mm}$ total length) (Bogan et al. 2014, Lytle 2015). These 2 smaller genera more commonly prey upon aquatic invertebrates, as well as terrestrial invertebrates that fall into aquatic habitats.

The diet of adult Red-legged Frogs consists of a wide taxonomic range of terrestrial and aquatic invertebrates and vertebrates. Specific prey items include amphibians, such as California Tiger Salamander (Ambystoma californiense) larvae, Sierran Treefrog (Pseudacris sierra), and California Toad (Anaxyrus boreas halophilus), as well as snakes (e.g., Common 


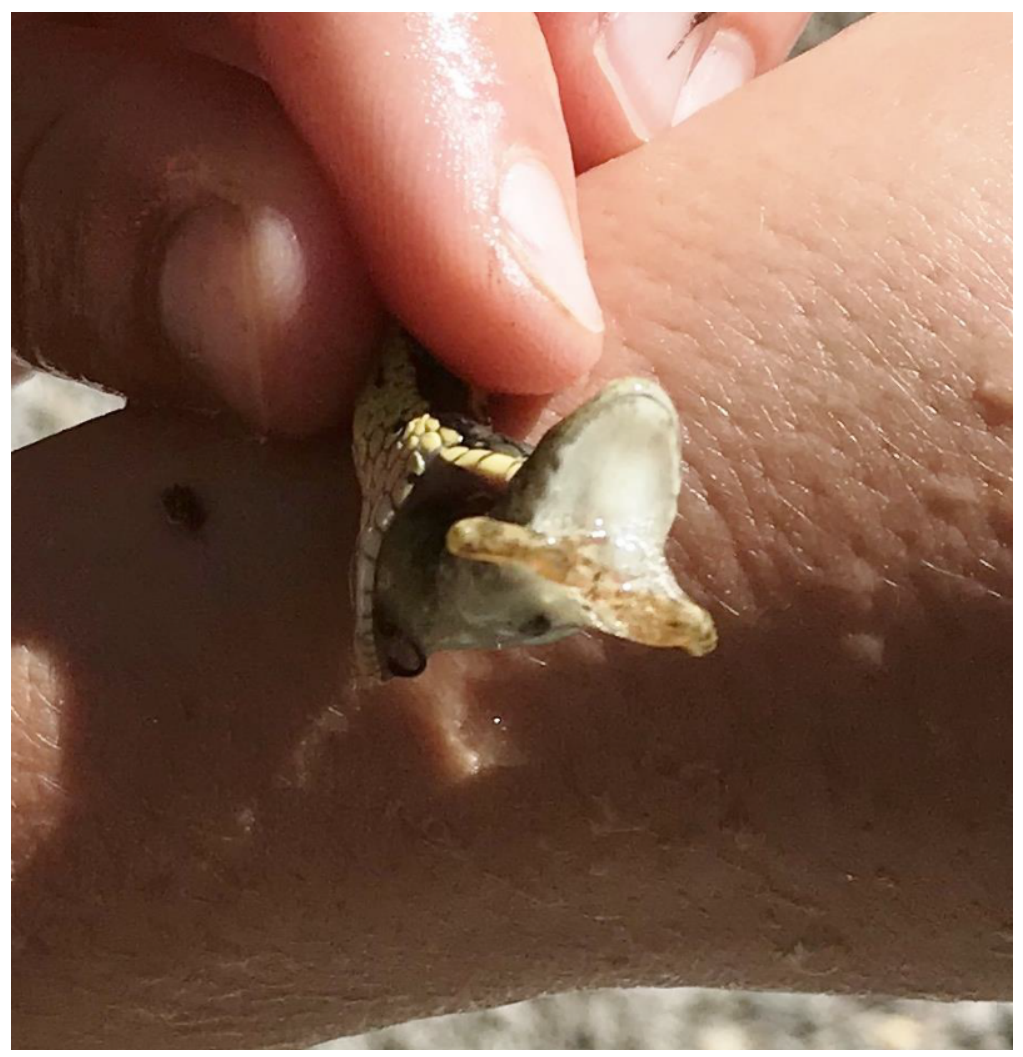

Fig. 2. Neonate Diablo Range Gartersnake (Thamnophis atratus zaxanthus) upon capture regurgitating a Foothill Yellow-legged Frog (Rana boylii) froglet, adjacent to an isolated pool along Coyote Creek, Diablo Range of central California, USA. Photo by S.M. Carlson.

Gartersnake [Thamnophis sirtalis]), fish (e.g., threespine stickleback [Gasterosteus aculeatus]), and several species of small rodents (Hayes and Tennant 1985, Baldwin and Stanford 1987, Hayes et al. 2006, Davidson 2010, Stitt and Seltenrich 2010). Because the California Red-legged Frog is known to prey on amphibians, it does not seem unusual that it would consume the closely related congener, Foothill Yellow-legged Frog, in pools where they co-occur. Our predation observation is consistent with the suggestion of Hayes and Tennant (1985) that California Red-legged Frog prey items occur mostly along the shoreline near the water surface.

Bishop et al. (2014) studied the diet of California Red-legged Frogs through isotope and stomach content analyses and found that $99.7 \%$ and $82 \%-90 \%$ of the diet, respectively, came from terrestrial prey. The high percentage of terrestrial prey items might be partially explained by the fact that many prey items originated from frogs captured in ponds, an aquatic environment unsuitable for Foothill Yellow-legged Frogs. Our predation observation was along a reach of intermittent stream, where Foothill Yellow-legged Frogs are locally abundant and therefore would be readily available as prey for California Red-legged Frogs. From 2014 to 2018, we documented the presence of Yellow-legged Frogs within our study reaches at $88.7 \%$ of the total sites where we observed adult California Redlegged Frogs $(n=62$; R. Leidy unpublished data). Bishop et al. (2014) posits that California Red-legged Frogs likely favor larger prey items to maximize foraging (i.e., metabolic) efficiency and reduce their own predation risk. Our observation of an adult Red-legged Frog consuming a large-sized adult Foothill Yellowlegged Frog is consistent with this contention.

The highly aquatic Diablo Range Gartersnake eats small frogs, such as Sierran treefrogs (Pseudacris sierra), salamanders and their 
larvae, fish, and invertebrates such as slugs and leeches (Preston and Johnson 2012). Aquatic gartersnakes are known to prey on the various life stages of Foothill Yellow-legged Frogs where their ranges overlap (Fitch 1936, 1940, 1941, Stebbins 1951, Zweifel 1955, Jennings and Hayes 1994, Bourque 2008). Our observation is significant in that it documents a neonate feeding on a relatively large-sized postmetamorph Foothill Yellow-legged Frog. This may indicate an ontogenetic shift in foraging strategy by this species from smaller to larger prey items, as observed for the Oregon Gartersnake (T. a. hydrophilus) (Lind and Welsh 1994).

In addition to the 3 predation events discussed above, other studies have documented that larval, postmetamorph, and adult Foothill Yellow-legged Frogs are prey for a wide variety of other invertebrates and vertebrates, including adults cannibalizing recent metamorphs (Moyle 1973, Rombough et al. 2005, Hothem et al. 2009, Kupferberg 1996, Ashton and Nakamoto 2007, Wiseman and Bettaso 2007, Olson and Davis 2009, Gonsolin 2010, Hayes et al. 2016). Within our study reach of Coyote Creek, Foothill Yellow-legged Frogs are often abundant within and adjacent to relatively small isolated pools embedded within long reaches of the dry streambed. For example, at one isolated pool measuring $8.5 \mathrm{~m}^{2}$ we documented a congregation of $>100$ individual postmetamorph and adult Foothill Yellowlegged Frogs (R. Leidy unpublished data). Similarly, we have observed Foothill Yellowlegged Frog tadpoles numbering 100 to $>1000$ in several other isolated pools (R. Leidy unpublished data). At such densities, Foothill Yellow-legged Frogs confined within relatively small patches of aquatic habitat likely play an important role in decomposition processes, critical trophic linkages, and the transfer of nutrients between intermittent aquatic (stream) and terrestrial (upland) ecosystems. Although permanent pools in intermittent streams may act as refuges for Foothill Yellow-legged Frogs, inhabiting these pools may also result in increased predation risk and mortality (Jennings and Hayes 1994, Rombough and Hayes 2005, Kupferberg et al. 2008).

The effects of predation on Foothill Yellowlegged Frog have been identified as a knowledge gap for which future research is needed (Hayes et al. 2016). One potentially fruitful avenue for future research is understanding whether there are seasonal dietary shifts by predators on Foothill Yellow-legged Frog as intermittent streams contract into isolated pools. Specifically, does a greater percentage of the diet of the California Red-legged Frog come from aquatic prey, such as the Foothill Yellow-legged Frog, as its densities increase within shrinking stream pools? And will Foothill Yellow-legged Frog populations be more vulnerable to their native predators under projected climate change scenarios for California, especially during drier years when less freshwater habitat is available?

\section{ACKNOWLEDGMENTS}

Coyote Creek is the ancestral homeland of the Amah Mutsun Tribal Band. We thank Henry Coe State Park for providing access to the study reaches at Coyote Creek. P. RodríguezLozano was supported by a Ramón Areces Foundation Postdoctoral Scholarship; M.T. Bogan was supported by a David H. Smith Conservation Research Fellowship administered by the Society for Conservation Biology; and S.M. Carlson was supported by the Rose Hills Fund from University of California, Berkeley. We thank P.L. Fiedler for review of the manuscript.

\section{Literature Cited}

Ashton, D.T., And R.J. NaKomoto. 2007. Rana boylii (Foothill Yellow-legged Frog) predation. Herpetological Review 38:442.

Baldwin, K.S., And R.A. Stanford. 1987. Ambystoma tigrinum californiense (California Tiger Salamander). Predation. Herpetological Review 18:33.

Bishop, M.R., R.C. Drewers, and V.T. VRedenburg. 2014. Food web linkages demonstrate importance of terrestrial prey for the threatened California Redlegged Frog. Journal of Herpetology 48:137-143.

Bogan, M.T., R.A. Leidy, L. Neuhaus, C.J. Hernandez, AND S.M. CARLSON. 2019. Biodiversity value of remnant pools in an intermittent stream during the great California drought. Aquatic Conservation: Marine and Freshwater Ecosystems. https://doi.org/10.1002/ aqc.3109

Bogan, M.T., N. Noriega-Felix, S.L. Vidal-Aguilar, L.T. Findley, D.A. Lylte, O.G. GutiérRez-Ruacho, J.A. Alvarado-Castro, and A. Varela-Romero. 2014. Biogeography and conservation of aquatic fauna in spring-fed tropical canyons of the southern Sonoran Desert, Mexico. Biodiversity And Conservation 23:2705-2748.

BourQue, R.M. 2008. Spatial ecology of an inland population of Foothill Yellow-legged Frog (Rana boylii) in Tehama County, California. Master's thesis, Humboldt State University, Arcata, CA. 93 pp. 
Davidson, C. 2010. Rana draytonii (California Redlegged Frog). Prey. Herpetological Review 41:66.

FIтcH, H.S. 1936. Amphibians and reptiles of the Rogue River basin, Oregon. American Midland Naturalist 17: 634-652.

Fitch, H.S. 1940. A biogeographical study of the ordinoides Artenkreis of garter snakes (genus Thamnophis). University of California Publications in Zoology 44:1-150.

FITCH, H.S. 1941. The feeding habits of California garter snakes. California Fish and Game 27:1-32.

Gonsolin, T.E. 2010. Ecology of Foothill Yellow-legged Frogs in Upper Coyote Creek, Santa Clara County, CA. Master's thesis, San Jose State University, San Jose, CA. 119 pp.

Hayes, M.P., M. Jennings, and G.B. Rathbun. 2006. Rana draytonii (California Red-legged Frog). Prey. Herpetological Review 37:449.

Hayes, M.P., and M.R. Tennant. 1985. Diet and feeding behavior of the California Red-legged Frog, Rana aurora draytonii (Ranidae). Southwestern Naturalist 30:601-605.

Hayes, M.P., C.A. Wheeler, A.J. Lind, G.A. Green, And D.C. Macfarlane. 2016. Foothill Yellow-legged Frog conservation assessment in California. United States Department of Agriculture, Forest Service, Pacific Southwest Research Station, Albany, CA.

Hothem, R.L., A.M. Meckstroch, K.E. Wegner, M.R. Jennings, And J.J. Crayon. 2009. Diets of three species of anurans from Cache Creek watershed, California, USA. Journal of Herpetology 43:275-283.

Jennings, M.R., And M.P. Hayes. 1994. Amphibian and reptile species of special concern in California. California Department of Fish and Game, Rancho Cordova, CA.

KupferberG, S.J. 1996. Hydrologic and geomorphic factors affecting conservation of a river-breeding frog (Rana boylii). Ecological Applications 6:1332-1344.

KupferberG, S.J., A.J. Lind, J.F. Mount, and S. Yarnell. 2008. Pulsed-flow effects on Foothill Yellow-legged Frog (Rana boylii): integration of empirical, experimental, and hydrodynamic modeling approaches - first year interim report. California Energy Commission, PIER Energy-related Environment Research Program.

LIND, A.J., AND H.H. WELSH. 1994. Ontogenic changes in foraging behaviour and habitat use by the Oregon garter snake, Thamnophis atratus hydrophilus. Animal Behaviour 48:1261-1273.
Lytle, D.A. 2015. Order Hemiptera. Pages 951-963 in J.H. Thorp and D.C. Rodgers, editors, Ecology and general biology: Thorp and Covich's freshwater invertebrates. Volume 1. 4th edition. Academic Press, San Diego, CA.

MoYLe, P.B. 1973. Effects of introduced bullfrogs, Rana catesbeiana, on native frogs of the San Joaquin Valley, California. Copeia 1973:8-22.

Онва, Shin-Ya. 2018. Ecology of giant water bugs (Hemiptera: Heteroptera: Belostomatidae). Entomological Science 22:6-20.

Olson, D.H., AND R.J. Davis. 2009. Conservation assessment for the Foothill Yellow-legged Frog (Rana boylii) in Oregon. USDA Forest Service, Region 6, and USDI Bureau of Land Management Interagency Special Status Species Program.

Preston, D.L., And P.T.J. Johnson. 2012. Importance of native amphibians in the diet and distribution of the Aquatic Gartersnake (Thamnophis atratus) in the San Francisco Bay Area of California. Journal of Herpetology 46:221-227.

Rombough, C.J., J. Chastain, A.M. Schwab, and M.P. HaYes. 2005. Rana boylii (Foothill Yellow-legged Frog). Predation. Herpetological Review 36:438-439.

Rombough, C.J., And M.P. Hayes. 2005. Rana boylii (Foothill Yellow-legged Frog) predation: eggs and hatchlings. Herpetological Review 36:163-164.

Stebirns, R.C. 1951. Amphibians of western North America. University of California Press, Berkeley, CA.

Stitt, E.W., And C.P. Seltenrich. 2010. Rana draytonii (California Red-legged Frog). Prey. Herpetological Review 41:206.

Thomson, R.C., A.N. Wright, and H.B. Shaffer. 2016. California amphibian and reptile species of special concern. University of California Press, Oakland, CA.

Wiseman, K.D., AND J. BetTaso. 2007. Rana boylii (Foothill Yellow-legged Frog). Cannibalism and predation. Herpetological Review 38:193.

ZwEIFEL, R.G. 1955. Ecology, distribution, and systematics of frogs of the Rana boylii group. University of California Publications in Zoology 54:207-292.

Received 28 November 2018

Revised 16 March 2019

Accepted 28 March 2019

Published online 18 June 2019 